\title{
Effects of Furosemide and Acute Salt Loading on Vasopressin and Renin Secretion in the Fetal Lamb
}

\author{
SHARON R. SIEGEL, ${ }^{(26)}$ ROSEMARY D. LEAKE, RICHARD E. WEITZMAN, AND \\ DELBERT A. FISHER \\ Department of Pediatrics, Fetal-Maternal Research Laboratories, Harbor-UCLA Medical Center, \\ Torrance, California, USA
}

\section{Summary}

Circulating arginine vasopressin (AVP) and plasma renin activity responses to furosemide $(2 \mathrm{mg} / \mathrm{kg})$ and acute hypertonic saline $(10 \mathrm{mEq} / \mathrm{kg})$ were studied in the fetal lamb from 100 days gestation to term. The baseline to peak plasma AVP response $(\Delta 3.7 \pm 1.2$ $\mathrm{uU} / \mathrm{ml})$ and area under the response curve $(209 \pm 57 \mathrm{uU} / \mathrm{ml} /$ $65 \mathrm{~min}$ ) in the fetal lambs $>123$ days were greater than in those $<106$ days gestation $(\Delta 1.8 \pm 1.1$ and $(171 \pm 61$, respectively), $P$ $<0.02$. The plasma renin activity/AVP ratio after furosemide was similar in the two gestational groups.

The log plasma AVP responses corrected for rise in plasma osmolality $(0.090 \pm .01 \mathrm{uU} / \mathrm{ml}) 30 \mathrm{~min}$ after infusion, and the area under the response curve $(253 \pm 49 \mathrm{uU} / \mathrm{ml} / 30 \mathrm{~min})$ was greater $(P<0.02)$ in the fetal lambs $>120$ days than in those under 115 days gestation $(.035 \pm 0.01$ and $88 \pm 29$, respectively), $P<0.02$. These results confirm that the fetal lamb responds to an osmotic stimulus with increased plasma AVP levels and documents that this response significantly matures during the last trimester of gestation. The fetal lamb also manifests a hypothalamus-posterior pituitary AVP response to furosemide that is proportional to the maturing renal renin response.

\section{Speculation}

There is a significant maturational plasma arginine vasopressin response to acute hypertonic saline and furosemide in the fetal lamb during the last trimester of gestation.

Arginine vasopressin (AVP) secretion normally appears to be regulated by at least two systems of receptors: osmoreceptors and volume receptors. Earlier studies have shown that the human newborn is capable of secreting AVP at birth and that both the osmoreceptor and volume control systems appear to be functional $(2,5,8)$. Similarly, increases in plasma AVP levels have been produced by both osmolar and volume (hemorrhage or transplacental water shifts) stimuli in the fetal sheep and monkey $(1,4,10$, $19,25)$, and earlier studies from our laboratories assessing volume and osmolar control sensitivity for AVP release in the newborn lamb have indicated sensitivity of both systems comparable to that of adult ewes (11). There is little data regarding the maturation of these responses in utero.

Recently, it has become apparent that the renin-angiotensin system also may influence AVP release (3, 9, 12-15), and Siegel et al. (18) have shown that furosemide stimulates AVP secretion in the newborn lamb and that this effect can be inhibited by an angiotensin II antagonist (saralasin acetate). There is no information regarding maturation of this response in utero. In the present study, we have examined the influence of gestational age on the plasma AVP response to an osmolar stimulus (hypertonic saline) and to furosemide stimulation in the fetal lamb model.

\section{MATERIALS AND METHODS}

Pregnant ewes were obtained from a local source and maintained in the vivarium prior to surgery. A uterotomy was performed using sterile technique, and arterial and venous catheters were placed in a hind leg. The fetus was returned to the uterine cavity, and the uterine incision was closed. The catheters were brought out through skin tunnels in the lateral abdominal wall and secured in a pouch attached to the back of the ewe. The animals were maintained on ampicillin for 5 days postoperatively and then studied. $\mathrm{pO}_{2}$ and $\mathrm{pH}$ values were normal at the time of study. Eleven fetal lambs 100 to 142 days of age (term, 145 days) were studied. Furosemide ( $2 \mathrm{mg} / \mathrm{kg}$ estimated fetal weight) was infused over 1 to $2 \mathrm{~min}$. Blood samples were drawn at $8,20,35$, and 65 min postinfusion.

In a separate study, hypertonic saline $(2.5 \mathrm{mEq} / \mathrm{ml})$ was infused at a dose of $10 \mathrm{mEq} / \mathrm{kg}$ over $2 \mathrm{~min}$. Blood samples were drawn at $3,7,15$, and 30 min postinfusion. Blood samples (total, $<5 \%$ blood volume) were replaced with an equal amount of isotonic saline. Plasma AVP $(20,24)$ was measured by radioimmunoassay after extraction with bentonite. Plasma renin was measured by radioimmunoassay after generation of angiotensin I (6). Plasma osmolality was measured using an Advanced Instruments 3R precision osmometer and sodium by flame photometry. Statistics were performed by direct difference $t$ test.

\section{RESULTS}

Circulating levels of plasma AVP and osmolality were similar between 100 to 142 days gestation in the fetal lambs. Figure 1 shows that furosemide administration did not increase plasma renin activity (PRA) and plasma AVP concentrations in the fetal lambs $<106$ days gestation. After 123 days gestation, PRA increased from a baseline of $17.2 \pm 3.2$ (mean \pm S.E.) to $26.1 \pm 5.2$ $\mathrm{ng} / \mathrm{ml} / \mathrm{hr}(P<0.01)$ at $20 \mathrm{~min}$ postinfusion. Plasma AVP increased from $1.4 \mathrm{uU} / \mathrm{ml}$ to $4.1 \pm 1.5$ at $65 \mathrm{~min}(P<0.05)$ postinfusion. The mean change from baseline to peak response in PRA in animals older than 123 days gestation was $\Delta 17.3 \pm 4.6$ $\mathrm{ng} / \mathrm{ml} / \mathrm{hr}(P<0.02)$; the mean change from baseline to peak in plasma AVP was $\Delta 3.7 \pm 1.2 \mathrm{uU} / \mathrm{ml}(P<0.02)$. Moreover, these responses in fetuses after 123 days gestation were significantly greater $(P<0.05)$ than those in fetuses under 106 days (Table 1$)$. In addition, the areas under the response curves for PRA and plasma AVP (Table 1) were more in fetuses of $>123$ days $(P<$ $0.05)$ gestation than in fetuses of $<106$ days gestation. However, the PRA/AVP concentration ratios following furosemide (Table 1) were similar at $<106$ and 123 days gestation. There were no changes in $\mathrm{pCO}_{2}, \mathrm{pO}_{2}, \mathrm{pH}$, or hemoglobin during the studies. There was no significant change in plasma sodium.

Plasma osmolality peaked at 3 min after completion of the acute saline infusion and started to decline after $7 \mathrm{~min}$ but did not return to baseline by $30 \mathrm{~min}$. The significant increment in osmo- 
lality in the fetal lambs $<115$ days gestation $(\Delta 19.1 \pm 6.3 \mathrm{mOsm} /$ liter) was similar to the also significant increase in fetal lambs $>121$ days gestation $(\Delta 23.5 \pm 2.3 \mathrm{mOsm} / \mathrm{liter})$. The significant plasma AVP responses to hypertonic saline at $30 \mathrm{~min}$ postinfusion $(\Delta 3.2 \pm 1.3 \mathrm{uU} / \mathrm{ml} ; P<0.05)$ in the fetal lambs $<115$ days gestation were significantly less than the responses $(\Delta 10.6 \pm 2.7$; $P<0.05$ ) in fetal lambs $>120$ days gestation (Fig. 2).

Table 2 compares the quantitative plasma AVP responses to hypertonic saline in the early and late fetuses and relates these responses to the changes in plasma osmolality. The mean baseline plasma AVP and osmolality were similar in the younger and older fetal lambs. The $30 \mathrm{~min}$ log plasma AVP response corrected for rise in osmolality was less in the early fetuses $(0.035 \pm 0 . \mathrm{uU} / \mathrm{ml})$ than in the older fetal lambs $(0.09 \pm 0.01 ; P<0.02)$. The plasma osmolality response expressed as area under the curve was 9317 \pm 77 and $9435 \pm 40$. The plasma AVP response expressed as area under the curve was less in the fetal lambs under 115 days gestation $(P<0.02)$ than in the older fetuses. There were not changes in $\mathrm{pCO}_{2}, \mathrm{pO}_{2}, \mathrm{pH}$, or hemoglobin during the studies.

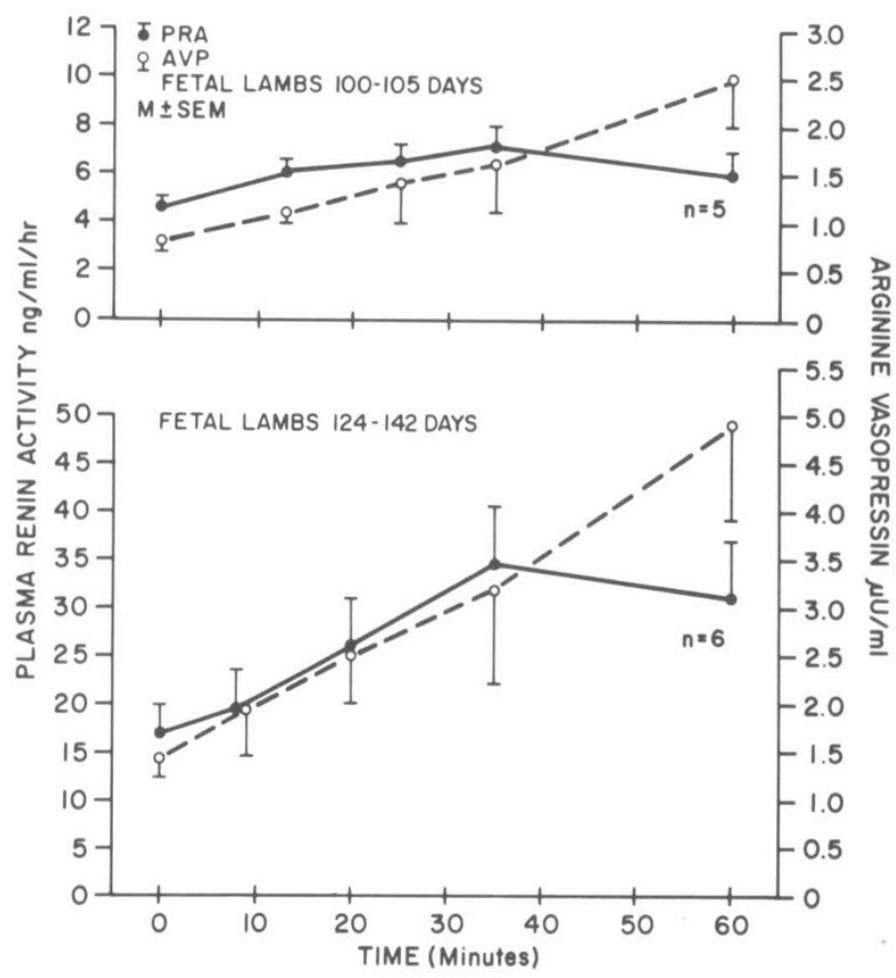

Fig. 1. The PRA and plasma AVP response to furosemide $(2 \mathrm{mg} / \mathrm{kg})$ over 1 to $2 \mathrm{~min}$ prior to $0 \mathrm{~min}$ time is shown in the fetal lamb. PRA and AVP concentrations did not increase after $<106$ days gestation; PRA increased from a baseline of $17.2 \pm 3.2$ (mean and S.E.) to $26.1 \pm 5.2 \mathrm{ng}$ / $\mathrm{ml} / \mathrm{hr}(P<0.01)$ at $20 \mathrm{~min}$ postinfusion. Plasma AVP increased from 1.4 $\mathrm{uU} / \mathrm{ml}$ to $4.1 \pm 1.5$ at $65 \mathrm{~min}(P<0.05)$ postinfusion.

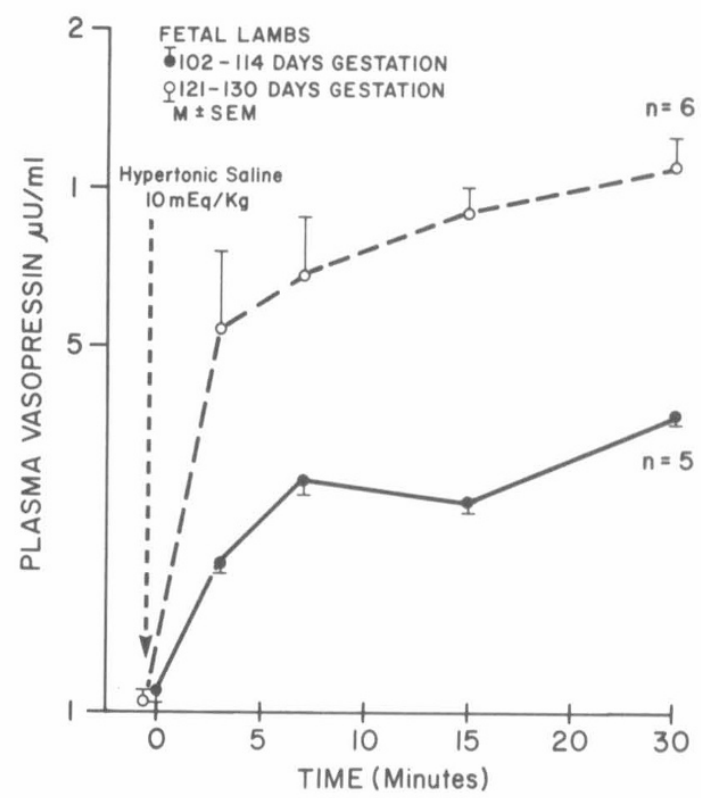

Fig. 2. The plasma AVP response to hypertonic saline $(10 \mathrm{mEq} / \mathrm{kg})$ over $2 \mathrm{~min}$ prior to $0 \mathrm{~min}$ time is shown in the fetal lamb. Plasma AVP increased from a baseline of $1.02 \pm 0.36$ (mean and S.E.) to $4.29 \pm 1.64$ $\mathrm{uU} / \mathrm{ml}(P<0.05)$ at $30 \mathrm{~min}$ postinfusion after $<115$ days gestation; plasma AVP increased from $1.11 \pm 0.24$ to $11.73 \pm 2.99 \mathrm{uU} / \mathrm{ml}(P<0.02)$ at 30 min postinfusion after $>120$ days gestation.

Figure 3 shows the PRA responses to acute salt loading in the two groups of fetuses. The saline infusion did not significantly alter PRA levels in either group.

\section{DISCUSSION}

In the present study, neither PRA nor plasma AVP could be stimulated by furosemide in fetal lambs under 106 days gestation (Fig. 1); after 123 days gestation, the PRA and plasma AVP response to furosemide was significant $(P<0.02)$. We have previously shown that furosemide stimulates plasma AVP in the newborn lamb via the renin-angiotensin system (18). A direct action of angiotensin II on the hypothalamic system is suggested by the fact that a cerebral intraventricular injection of angiotensin II promptly stimulates AVP release $(9,12-14)$; when saralasin is simultaneously infused directly into a cerebral ventricle, the AVP response to intraventricular renin or angiotensin II is totally inhibited $(3,12,15)$. Both angiotensin (21) and saralasin (7) cross the blood-brain barrier; and a high enough dose of saralasin given peripherally will inhibit the central effects of angiotensin II (7). Conversely, AVP administration has been shown to suppress renin release $(17,22)$ from the kidney. Inasmuch as the PRA/AVP ratios were similar in the younger and older fetal lambs and in the newborn lambs (18), this suggests that the proportionally augmented mean plasma AVP response with maturation may be related to the greater PRA response with maturation. Rudolph

Table 1. PRA and plasma AVP responses to furosemide in fetal lambs

\begin{tabular}{|c|c|c|c|c|c|c|}
\hline \multirow[b]{2}{*}{$\begin{array}{c}\text { Gestational age } \\
\text { (days) }\end{array}$} & \multirow[b]{2}{*}{$N^{\prime}$} & \multicolumn{2}{|c|}{ PRA (ng/ml/hr) } & \multicolumn{2}{|c|}{$\operatorname{AVP}(\mu \mathrm{U} / \mathrm{ml})$} & \multirow[b]{2}{*}{ PRA/AVP ${ }^{2}$} \\
\hline & & $\begin{array}{l}\text { Baseline to peak } \\
\text { response }\end{array}$ & Area under curve & $\begin{array}{l}\text { Baseline to peak } \\
\text { response }\end{array}$ & Area under curve & \\
\hline $100-105$ & 5 & $\Delta 5.0 \pm 1.9^{3}$ & $843 \pm 88$ & $\Delta 1.8 \pm 1.1$ & $171 \pm 61$ & $6.64 \pm 2.38$ \\
\hline $123-142$ & 6 & $\Delta 17.3 \pm 4.6^{4}$ & $2007 \pm 313$ & $\Delta 3.7 \pm 1.2^{4}$ & $209 \pm 57$ & $13.83 \pm 3.98$ \\
\hline
\end{tabular}

\footnotetext{
${ }^{1} N$, number of animals.

${ }^{2}$ Ratio of areas under curve.

${ }^{3}$ Mean \pm S.E.

${ }^{4} P<0.02$.
} 
Table 2. Plasma AVP response to acute salt loading as a function of gestational age

\begin{tabular}{|c|c|c|c|c|c|c|}
\hline $\begin{array}{c}\text { Gestational age } \\
\text { (days) }\end{array}$ & $N^{1}$ & $\begin{array}{c}\text { Baseline pAVP } \\
(\mu \mathrm{U} / \mathrm{ml})\end{array}$ & $\begin{array}{c}\text { Baseline pOsm } \\
\text { (mOsm/liter) }\end{array}$ & $\begin{array}{c}\text { Log AVP } 30 \mathrm{~min} \\
-\log \text { AVP baseline } \Delta \text { Osm } \\
\Delta \text { Osm }\end{array}$ & $\begin{array}{c}\mathrm{pAVP}(\mu \mathrm{U} / \mathrm{ml} / 30 \\
\min )\end{array}$ & $\mathrm{pOsm}^{2}(\mathrm{mOsm} / \mathrm{liter} / 30 \mathrm{~min})$ \\
\hline $101-114$ & 5 & $1.02 \pm 0.38^{3}$ & $283 \pm 3.3$ & $0.035 \pm 0.01^{4}$ & $88 \pm 29^{4}$ & $9317 \pm 77$ \\
\hline $121-130$ & 6 & $1.11 \pm 0.25$ & $282 \pm 2.0$ & $0.090 \pm 0.01^{4}$ & $253 \pm 49^{4}$ & $9435 \pm 40$ \\
\hline
\end{tabular}

${ }^{1} N$, number of animals.

${ }^{2}$ Areas under response curves.

${ }^{3}$ Mean and S.E.

${ }^{4} P<0.02$.

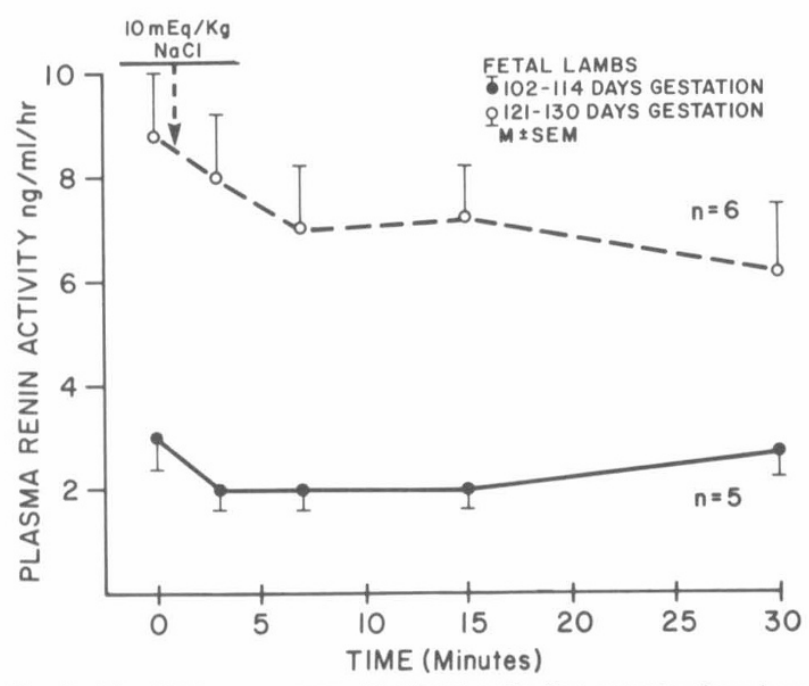

Fig. 3. The PRA response to $\mathrm{NaCl}(10 \mathrm{mEq} / \mathrm{kg})$ over 2 min prior to 0 min time in the fetal lamb. The saline infusion did not significantly alter PRA level in either group.

(16) infused AVP in fetal lambs and found a rise in arterial blood pressure. Because AVP can be stimulated by the renin-angiotensin system in the fetal and newborn lamb (18), this suggests that AVP may play an ancillary role in blood pressure homeostasis.

The present results suggest that there is a progressive maturation of the hypothalamic-posterior pituitary AVP response to an osmolar stimulus (Fig. 2; Table 2); PRA does not vary in response to the osmolar stimulus (Fig. 3). In an earlier report from our laboratory, we described an exponential relationship between plasma AVP concentration and plasma osmolality in the adult ewe such that the log of plasma AVP is a linear function of plasma Osm (23). Also, in an earlier collaborative study (24), we reported that a hypertonic saline infusion $(5 \% \mathrm{NaCl}$ solution) resulted in a similar increase in the log plasma AVP (corrected for the rise in plasma Osm) in fetal lambs under and over 120 days gestation (25). This result is in contrast to our present data. However, the volume of the hypertonic saline in the earlier study varied from 7 to $20 \mathrm{ml} / \mathrm{kg}$, and the duration of infusion ranged from 14 to 31 min with plasma AVP and plasma Osm levels peaking at varying times. In the present study, a uniform dose $(10 \mathrm{mEq} / \mathrm{kg})$ of hypertonic saline was infused over $2 \mathrm{~min}$, and the plasma Osm and AVP levels peaked at similar times in all fetuses. Also, the blood samples were mailed from Iowa to California in the previous study, which could have contributed to the difference in results.

\section{REFERENCES AND NOTES}

1. Alexander, D. P., Britton, H. G., Forsling, M. L., Nixon, D. A., and Ratcliff, J. G.: Pituitary and plasma concentrations of adrenocorticotrophin, growth hormone, vasopressin, and oxytocin in fetal and maternal sheep during the latter half of gestation and the response to hemorrhage. Biol. Neonate, 24: 206 (1974).
2. Chard, T., Hudson, C. N., Edwards, C. R. W., and Boyd, N. R. H.: The release of oxytocin and vasopressin by the human foetus during labor. Nature (Lond.), 234: 352 (1971).

3. Cooling, M. J., and Day, M. D.: Inhibition of renin-angiotensin induced drinking in the cat by enzyme inhibitors and by analogue antagonists of angiotensin II. Clin. Exp. Pharmacol. Physiol., 1: 389 (1974).

4. Drummond, W. H., Rudolph, A. M., Keil, L. C., and Heymann, M. A.: Arginine vasopressin (AVP) in fetal lambs and response to blood loss. Pediatrics, 11: 405 (1977).

5. Fisher, D. A., Pyle, H. R., Porter, I. C., Beard, A. G., and Panas, T. C.: Studies of control of water balance in the newborn. Am. J. Dis. Child., 106: 137 (1963).

6. Haber, E., Koerner, T., Page, L. B., Kliman, B., and Furnode, A.: Application of a radioimmunoassay for angiotensin I in normal subjects. J. Clin. Endocrinol Metab., 29: 1349 (1969).

7. Hoffman, W. E., and Phillips, M. I.: Evidence for $\operatorname{Sar}^{1}$-ala ${ }^{8}$-angiotensin crossing the blood cerebrospinal fluid barrier to antagonize central effects of angiotensin II. Brain Res., 109: 541 (1976).

8. Hoppenstein, I. M., Miltenberger, F. W., and Moran, W. H., Jr.: The increase in blood levels of vasopressin in infants during birth and surgical procedures. Surg. Forum, 18: 292 (1967).

9. Keil, L. C., Summy-Long, J., and Severs, W. F.: Release of vasopressin by angiotensin II. Endocrinology, 96: 1063 (1975).

10. Leake, R. D., Weitzman, R. E., Effros, R. M., Siegel, S. R., and Fisher, D. A. Maternal fetal osmolar homeostasis: fetal posterior pituitary autonomy. Pediatr. Res., 13: 841 (1979).

11. Leake, R. D., Weitzman, R. E., Weinberg, J. A., and Fisher, D. A.: Control of vasopressin secretion in the newborn lamb. Pediatr. Res., 13: 257 (1979).

12. Malayan, S. A., and Reid, I. A.: Antidiuresis produced by injection of renin into the third cerebral ventricle of the dog. Endocrinology, 98: 329 (1976).

13. Malvin, R. L.: Possible role of the renin-angiotensin system in the regulation of antidiuretic hormone. Fed. Proc., 30: 1383 (1971).

14. Mouw, D., Bonjour, J. P., Malvin, R. L., and Vander, A. J.: Central action of angiotensin in stimulating ADH release. Am. J. Physiol., 220: 239 (1971).

15. Reid, I. A., and Ramsay, D. J.: The effects of intracerebroventricular administration of renin on drinking and blood pressure. Endocrinology, 97: 536 (1975).

16. Rudolph, A.: Homeostasis of the fetal circulation and the part played by hormones. Ann. Rech. Vet., 8: 405 (1977).

17. Shade, R. E., Davis, J. O., Johnson, J. A., Gotshall, R. W., and Spielman, W. S. Mechanism of action of angiotensin II and antidiuretic hormone on renin secretion. Am. J. Physiol., 224: 926 (1973).

18. Siegel, S. R., Weitzman, R. E., and Fisher, D. A.: Endogenous angiotensin stimulation of vasopressin in the newborn lamb. J. Clin. Invest., 63: 287 (1979).

19. Skowsky, W. R., Bashore, R. A., Smith, F. G., and Fisher, D. A.: Vasopressin metabolism in the foetus and newborn, In: K. W. Cross: G. S. Davies, and P. W. Nathanielsz: Foetal and Neonatal Physiology. p. 439 (Cambridge University Press, London, 1973).

20. Skowsky, W. R., Rosenbloom, A., and Fisher, D. A.: Radioimmunoassay of arginine vasopressin development and application. J. Clin. Endocrinol. Metab., 38: 278 (1974).

21. Summy-Long, J., and Severs, W. B.: Angiotensin and thirst: studies with a converting enzyme inhibitor and a receptor antagonist. Life Sci., 15: 569 (1974).

22. Vander, A. J.: Inhibition of renin release in the dog by vasopressin and vasotocin. Circ. Res., 23: 605 (1968).

23. Weitzman, R. E., and Fisher, D. A.: Log linear relationship between plasma arginine vasopressin and plasma osmolality. Am. J. Physiol., 233: E37 (1977).

24. Weitzman, R. E., Fisher, D. A., DiStefano, J. J., III, and Bennett, C. M.: Episodic secretion of arginine vasopressin. Am. J. Physiol., 233: E32 (1977).

25. Weitzman, R. E., Fisher, D. A., Robillard, J., Erenberg, A., Kennedy, R., and Smith, F.: Arginine vasopressin response to an osmotic stimulus in the fetal sheep. Pediatr. Res., 12: 35 (1978).

26. Requests for reprints should be addressed to: Sharon R. Siegel, M.D., UCLA, Division of Nephrology, 52-175, Los Angeles, CA 90024 (USA).

27. This research was supported by Grants I R01, HD 10611-02, and HD-06335 from the National Institutes of Health.

28. Received for publication April 23, 1979.

29. Accepted for publication September 26, 1979. 